\title{
Basic Demographic Processes in Croatia
}

\author{
Dražen Živić, Nenad Pokos and Ivo Turk
}

\begin{abstract}
The paper describes the basic processes of contemporary development of the Croatian population: total, natural and emigrational depopulation and demographic ageing. The causal connection between the processes of general and partial depopulation is explained and the results indicate their far-reaching unfavourable effects to the future development of Croatian population.
\end{abstract}

Key words: Croatia, population, total depopulation, natural depopulation, demographic ageing

\section{Glavni demografski procesi u Hrvatskoj}

U radu se razmatraju glavni demografski procesi u suvremenom razvoju hrvatskog stanovništva: ukupna, prirodna i emigracijska depopulacija i demografsko starenje. Objašnjava se međusobna kauzalnost procesa opće i parcijalne depopulacije. Rezultati upućuju na njihove dalekosežne negativne posljedice u budućem razvoju hrvatskog stanovništva.

Ključne riječi: Hrvatska, stanovništvo, ukupna depopulacija, demografsko starenje

\section{INTRODUCTION}

The development of the Croatian population in the contemporary period (after the World War II) is characterized by several general (basic) and partial (specific) demographic processes that imply a marked depopulation. The most important among them are the processes of total and natural depopulation and of demographic ageing (Wertheimer-Baletić, 2004). These long-term demographic processes, causally inter-related and with far-reaching consequences, became an important disturbing factor not only of the stable and natural population development but also of the overall socio-economic development of Croatia. Croatia belongs to the circle of the European countries faced with markedly unfavourable demographic processes, trends, relations and structures. In fact, "demographic trends observed in the natural change of the Croatian population, mainly in the change of vital rates (natality, mortality and natural change) as well as in the change of the age structure and in the rapid ageing of the population in particular, correspond to the trends of many western European countries (Austria, Germany, Italy, Switzerland, Norway, Sweden and others)" (Wertheimer-Baletić, 1996, 252). An aggravating feature of the development of 
the Croatian population is the fact that an accelerated pace of demographic changes are not followed by the same, but by lower level of socio-economic development, which generates numerous problems and disturbances in both demographic and total development of the country.

This described situation is the result of causal conditionality and permeation of various interior and exterior determinants of demographic development, many of which had affected, or are still affecting the development of the Croatian population in a destabilizing way. Demographic development should be considered in terms of its complex interdependence and interaction with all relevant social, economic, historical, political, cultural and other processes and events in a community. In that context, it is important to note that over the past hundred years the Croatian population has been developing under the influence of continuous, and sporadically intense emigration into Western Europe and overseas. There are several factors that lead to this: negative influences of the two world wars, illnesses and frequent epidemics such as those of cholera and Spanish flu, and frequent deep economic crises, especially in agricultural production. These destabilizing factors were further augmented by the economic emigration which started in the $1960 \mathrm{~s}$ and was mainly caused by the uncontrolled, even forced deagrarization (reduction of employment in agriculture), deruralization (emigration from rural areas) and by the rapid and excessive urbanization leading to over-population of larger towns (Akrap, 1998). Owing to the specific geographical location of Croatia characterized by good communications between different European regions but also by tumultuous historical, political and social processes that had often resulted in territorial changes, the Croatian territory has been an "open migratory area" for many centuries from the emigration and immigration aspects (Wertheimer-Baletić, 1992). In other words, migrations are an extremely important determinant of the development of Croatian population. Their effect can be seen in the change of number of inhabitants and distribution of population as well as in the development of demographic structures, especially in relation to the ethnic and religious composition of the population. In addition to economic and political factors, the war-related events and losses greatly affected the spatial dynamics of the Croatian population. In that context, four big waves of emigration from Croatia can be determined: (1) from 1880s until World War I (overseas emigration); (2) at the end of World War II (emigration overseas and into Western Europe); (3) in the 1960s (leaving to so called "temporary work abroad"); (4) in the 1990s (emigration into Western Europe and partly overseas) (Akrap, 2003). The last great wave of emigration from Croatia definitely involves the forced migrations of the Croatian population (refugees/exiled) caused by Serbian military aggression. The size of total emigrational contingent from Croatia has not yet been accurately researched and determined. However, it is probably very close to assume that from the middle of $19^{\text {th }}$ until the end of the $20^{\text {th }}$ century approximately 1,3 million persons had emigrated from Croatia (Nejašmić, 1991; Pokos, 1999).

Along with the other destabilizing factors of demographic development (war-losses, illnesses, epidemics, demographic ageing, etc.), emigration from Croatia has initiated unfavourable processes in natural population dynamics, especially in natality. These processes resulted in the disturbed development of certain demographic structures, especially with respect to age and sex composition, economic and family structure of the population, 
which in turn induced manifestly unfavourable effects on reproduction, migratory processes and on overall social and economic development of the country. Until the early 1990s, destabilizing effects of mentioned determinants on the development of the Croatian population were augmented by: (1) the absence of any comprehensive, long-term and stimulating population and family policy, especially in the domain of natality dynamics, and (2) by the war and war-related relatively great actual (direct and migratory) and indirect demographic losses that intensified all negative and halted already rare positive processes in the development of the Croatian population. For the purpose of this paper, it is sufficient to summarize that according to available data the number of killed, dead or missing due to the war and its consequences exceeds 20,000 persons; around 500,000 persons were exiled from their homes and more that 100,000 persons fled to Western Europe and overseas countries. Serbian emigrational/refugee contingent from Croatia comprised more than 300,000 persons at the peak of the emigration/refugee wave (Živić, 1999, 2001; Živić \& Pokos, 2002, 2004).

\section{TOTAL DEPOPULATION OF CROATIA}

The term total depopulation means a decline in the total number of inhabitants recorded between the two consequent censuses or between two selected years (WertheimerBaletić, 1999). Croatia's first decline in the number of inhabitants, after World War II, was recorded during the last 1991-2001 intercensus period. However, total depopulation is a long-term process that is preceded or determined by various partial processes such as natural, generational, reproductional and emigrational depopulation. Croatia has been faced with the deceleration of the demographic growth rates over a considerably long period of time. This is the result of the previously mentioned inherited destabilizing factors of population development. The most important among them is interaction of continuous drop in the natality (leading to natural depopulation) and strong emigration and demographic ageing. From 1953 to 1991, the average annual population growth rate of the Croatian population had been constantly declining (from $0.8 \%$ in the period $1948-1953$ to $0.4 \%$ in the period $1981-1991)$.

Tab. 1 Population change and indicator of the population change in Croatia (1948 - 2001)

Tab. 1. Kretanje broja i pokazatelj promjene stanovništva Hrvatske između 1948. i 2001.

\begin{tabular}{|c|c|c|c|c|}
\hline Year & $\begin{array}{c}\text { Number of } \\
\text { inhabitants }\end{array}$ & Chain index & $\begin{array}{c}\text { Base index } \\
(\mathbf{1 9 4 8}=\mathbf{1 0 0})\end{array}$ & $\begin{array}{c}\text { Average annual } \\
\text { change (\%) }\end{array}$ \\
\hline 1948 & $3.779,858$ & - & 100 & - \\
\hline 1953 & $3.936,022$ & 104.1 & 104.1 & 0.8 \\
\hline 1961 & $4.159,696$ & 105.7 & 110.0 & 0.7 \\
\hline 1971 & $4.426,211$ & 106.4 & 117.1 & 0.6 \\
\hline 1981 & $4.601,469$ & 104.0 & 121.7 & 0.4 \\
\hline 1991 & $4.784,265$ & 104.0 & 126.6 & 0.4 \\
\hline 2001 & $4.437,460$ & 92.8 & 117.4 & -0.7 \\
\hline
\end{tabular}

Source: Statistički ljetopis Republike Hrvatske 2001., DZSRH, Zagreb, 2001. Popis stanovništva 2001., DZSRH, Zagreb, 2002. (www.dzs.hr) 
Setting aside to a certain degree the problem of methodological (in)comparability of the 1991 and $2001^{1}$ census data, it is evident that between the mentioned years the number of Croatian inhabitants reduced by almost 350,000 (7.2\%). By applying the 1991 definition of the total population (de iure) to 2001 census data, the total depopulation in Croatia is $6,1 \%$. However, if only the population actually present in the country is considered and counted by the census (de facto), the total depopulation in Croatia increases to $6.6 \%$. These comparisons, though meant only as an indication of a trend, clearly indicate that total depopulation in Croatia has been a long-term process with historically distant and deep roots. Moreover, both components are playing role in the decline of the Croatian population: natural dynamics and migrations, have had pronounced negative developmental characteristics for a considerably long time (Wertheimer-Baletić, 2003).

\section{NATURAL DEPOPULATION OF CROATIA}

Natural depopulation is a term indicating natural decrease of the population caused by an excess of deaths over live births (Wertheimer-Baletić, 1999). In isolated populations, where migrations do not affect demographic development, natural depopulation means also total depopulation. In "open populations", that is, in populations that communicate with other populations through migrations, natural depopulation is not necessarily the only factor of the population decrease. In that case, the total depopulation frequently depends upon the relation between the emigration and immigration. However, the natural dynamics of population is still regarded as the most important component and determinant of total depopulation.

Negative tendencies in natural population dynamics, especially in the dynamics of natality, had been one of the most important internal destabilizing factors of the development of the Croatian population for the past $30-40$ years. In that context, the long lasting, almost continuous fall in the number of live births (and natality rates) should be emphasized along with the decrease in total fertility rate, general and age-specific fertility rates and in net reproduction rate of the Croatian population. At the same time, the mortality (the number of deaths and mortality rates) is in a slight, but constant, increase.

Back in the late 1950s, the rate of the net reproduction in Croatia dropped below the figure of 1.0, which represents the threshold value to ensure at least simple generational reproduction of the female population. This implies that for more than forty years the process of generational depopulation had persisted in Croatia. This process directly affected the decrease of natality by reducing the total and specific fertility rates (per age groups). Total fertility rate $^{2}$ in Croatia dropped below the value of 2.1 , which represents the ability of simple generational reproduction of total population in the year 1968 (Wertheimer-Baletić, 1992). In the year 2001 the total fertility rate in Croatia was 1.38 , which was one of the lowest values in Europe. That year, or one or two years earlier (depending on the available data), the total fertility rate higher than Croatia (1.38) reported the following European countries: Albania (2.10; in the year 1999), Iceland (2.08), Ireland (1.97), France (1.90), Norway (1.78), Denmark (1.74), Finland (1.73), Macedonia (1.73), Netherlands (1.71), 
Belgium (1.66), Serbia and Montenegro (1.66), United Kingdom (1.63), Sweden (1.57), Portugal (1.46), Switzerland (1.41), etc. The following European countries had lower total fertility rate than Croatia: Estonia (1.34), Austria (1.31), Hungary (1.31), Lithuania (1.30), Poland (1.29), Belarus (1.27), Spain (1.26), Bulgaria (1.24), Italy (1.24), Romania (1.24), Latvia (1.21), Slovenia (1.21), Slovakia (1.20), Czech Republic (1.14), Ukraine (1.10; in the year 1999) ${ }^{3}$, etc. Among numerous determinants responsible for the fertility decrease in Croatia, as well as in most European countries, there are two factors that must be stressed: (1) fertility control by means of contraceptives and birth control, and (2) education and employment of women (increased participation in economic activity of the female population) (Puljiz, 1995).

In other words, since the late 1960s, another pattern of depopulation process in reproduction appeared in Croatia - the reproduction depopulation. These partial processes in the reproduction of the Croatian population - the processes of generational and reproduction depopulation are the most important factors of the unfavourable tendencies in the natality dynamics, and - in the long run - of the total natural dynamics of the Croatian population. Thus, the generational and reproduction depopulation directly preceded and in many aspects contributed to the onset and development of the natural depopulation of Croatia in early 1990 s.

Taking into consideration the past thirty years $(1971-1991)$, it is evident that the number of live born children in Croatia dropped from 61,673 to 39,668 , or by $35.7 \%$. In that period, the highest number of live births registered was in $1979(65,111)$, and the lowest in $2003(39,668)$. When those two years are compared, the drop of natality was no less than $39.1 \%$. Since 1997, the absolute value of the natality in Croatia is in continuous decrease. In the period from 1997 to 2003, the number of live births in Croatia was reduced by $18.4 \%$.

The natality dynamics in Croatia over the past thirty years has had two significant characteristics: (1) during the second half of the 1970s, there was a slight increase in the number of live births resulting from the fact that generations born in the compensational period (baby boom) after World War II reached their fertile age (15 - 49 years of age); and (2) that period was followed with a rapid drop of natality resulting from the fact that fewer generations reached their fertility and were capable for reproduction, due to either emigration or natality drop during the 1960s.

In the investigated period $(1971-2003)$ the number of deaths in Croatia increased from 44,538 to $52,575(18.0 \%)$. Over these thirty years the mortality was the lowest in $1971(44,538)$ and the highest in $1983(54,635)$. Although the mortality (especially the absolute values) oscillates in its dynamics more than natality, the tendency of its increase is clearly evident. The increase in mortality growth was especially significant at the beginning of the 1980 s and 1990s. In the case of the $1980 \mathrm{~s}$, the number of deaths was determined by the fact that generations born in the compensation period after World War I reached older age, with an increased risk of dying. In the case of the 1990s, increase in mortality was directly determined by war demographic losses caused by Serbian military aggression, by prolongation of human life and intensified process of population ageing. 
Tab. 2 The dynamics of live births and deaths in Croatia (1971 - 2003)

Tab. 2. Kretanje broja živorođenih i umrlih u Hrvatskoj u razdoblju 1971.-2003. godine

\begin{tabular}{|c|c|c|c|c|c|}
\hline Year & Live births & Deaths & $\begin{array}{c}\text { Natural } \\
\text { change }\end{array}$ & $\begin{array}{c}\text { Index of } \\
\text { live births } \\
\text { dynamics }\end{array}$ & $\begin{array}{c}\text { Index of } \\
\text { deaths } \\
\text { dynamics }\end{array}$ \\
\hline 1971 & 61,673 & 44,538 & 17,135 & - & - \\
\hline 1972 & 61,487 & 47,532 & 13,955 & 99.7 & 106.7 \\
\hline 1973 & 61,311 & 45,285 & 16,026 & 99.7 & 95.3 \\
\hline 1974 & 60,538 & 44,554 & 15,984 & 98.7 & 98.4 \\
\hline 1975 & 61,045 & 45,175 & 15,870 & 100.8 & 101.4 \\
\hline 1976 & 61,876 & 44,670 & 17,206 & 101.4 & 98.9 \\
\hline 1977 & 63,296 & 44,799 & 18,497 & 102.3 & 100.3 \\
\hline 1978 & 64,023 & 48,325 & 15,698 & 101.1 & 107.9 \\
\hline 1979 & 65,111 & 48,003 & 17,108 & 101.7 & 99.3 \\
\hline 1980 & 64,904 & 49,640 & 15,265 & 99.7 & 103.4 \\
\hline 1981 & 63,885 & 50,953 & 12,932 & 98.4 & 102.6 \\
\hline 1982 & 64,810 & 50,167 & 14,643 & 101.4 & 98.5 \\
\hline 1983 & 63,138 & 54,635 & 8,503 & 97.4 & 108.9 \\
\hline 1984 & 63,066 & 53,720 & 9,286 & 99.9 & 98.3 \\
\hline 1985 & 60,886 & 51,610 & 9,276 & 96.5 & 96.1 \\
\hline 1986 & 58,181 & 51,233 & 6,948 & 95.4 & 99.3 \\
\hline 1987 & 57,328 & 52,493 & 4,835 & 98.5 & 102.5 \\
\hline 1988 & 56,964 & 52,192 & 4,772 & 99.4 & 99.4 \\
\hline 1989 & 54,170 & 52,039 & 2,131 & 95.1 & 99.7 \\
\hline 1990 & 53,869 & 51,752 & 2,117 & 99.4 & 99.4 \\
\hline 1991 & 50,815 & 54,311 & $-3,496$ & 94.3 & 104.9 \\
\hline 1992 & 44,679 & 51,323 & $-6,644$ & 87.9 & 94.5 \\
\hline 1993 & 46,106 & 50,219 & $-4,113$ & 103.2 & 97.8 \\
\hline 1994 & 45,426 & 48,802 & $-3,376$ & 98.5 & 97.2 \\
\hline 1995 & 45,671 & 49,826 & $-4,155$ & 107.6 & 102.1 \\
\hline 1996 & 48,218 & 49,657 & $-1,439$ & 105.6 & 99.7 \\
\hline 1997 & 48,604 & 50,801 & $-2,197$ & 100.8 & 102.3 \\
\hline 1998 & 47,068 & 52,311 & $-5,243$ & 96.8 & 103.0 \\
\hline 1999 & 45,179 & 51,953 & $-6,774$ & 96.0 & 99.3 \\
\hline 2000 & 43,746 & 50,246 & $-6,500$ & 99.3 & 97.8 \\
\hline 2001 & 40,993 & 49,552 & $-8,859$ & 93.7 & 98.6 \\
\hline 2002 & 40,094 & 50,569 & $-10,475$ & 97.8 & 102.1 \\
\hline 2003 & 39,668 & 52,575 & $-12,907$ & 98.9 & 123.2 \\
\hline
\end{tabular}

*Note: Considered is vital dynamics "in the country", according to the methodology for collecting data for vital dynamics that is applied from 1998.

Source: Prirodno kretanje stanovništva 1971. - 2002., RZSSRH i DZSRH, Zagreb, 1973. - 2004 Priopćenje br. 7.1.1. Prirodno kretanje stanovništva RH u 2003., DZSRH, Zagreb, 2004. 
The tendencies in the natality and mortality dynamics, caused corresponding changes in the total dynamics of the Croatian population. In the period from 1971 to 1977 , the absolute values of natural dynamics of the population oscillate mainly above the number of 15,000 inhabitants. This is the result of a relatively high number of live births. However, after 1977, with the exception of the years 1979 and 1982, there was an extremely rapid drop of natural population growth (from 18497 in 1977 to only 2,117 in 1990, which is the decrease of as much as $88.6 \%$ ). In the beginning of the $1990 \mathrm{~s}$, the reduction of the natural growth of the Croatian population was not halted, but rather intensified, which resulted in the process of natural depopulation (in 1991, the number of deaths exceeded the number of live births by 3,496 persons). This led to a breakdown in the natural dynamics of the Croatian population. In 1992 the range of the natural depopulation was 6,644 persons. The process of natural depopulation in Croatia was induced and intensified by the following factors: continuous decrease of the natality that lasted for almost half of the century, rapid demographic ageing, war mortality caused by the Serbian military aggression, the drop of nuptiality ("depressed" natality), heavy burden of anti-natality concept in the population reproduction (so called "white plague"), uneven sex structure of the population, continuation of intense emigration and heavy economic, social and political circumstances that had unstimulating effect on the number of births. Natural growth of 17,135 persons from 1971 turned into a natural drop of no less than 12,907 persons in 2003. It could be estimated that, in the period 1991-2001, the natural depopulation in Croatia exceeded 65,000 persons $^{4}$. During the recent period of only five years $(1999-2003)$, the natural drop of the population was 45,215 persons, which means that a town the size of Varaždin or bigger "disappeared" by extinction!

Because of negative trends in the natural dynamics of the population, with the tendency of further deteriorating, Croatia has lost the core of population that can take part in reproduction and work (Živić, 2003, b). Decrease in the natality implies the decline of young population, which represents the demographic basis for reproductive and working contingent of the population. Thus, the natality, as well as the natural change of the population in its wider context, directly determines the composition of the population with respect to age and activity, as the most important vital and economic demographic structures. Therefore, the negative processes in the natural dynamics of the population are considered to be the crucial factors of disturbances in the age and sex structure of a population.

Significant contemporary determinants of the natality decrease and natural depopulation of Croatia involve also the changes in the family structure and in nuptiality and divorce rate. It is important to note that changes in the natural dynamics and in the development of age and sex structure of the Croatian population, as well as those seen in social and economic development of the country, have greatly influenced the dynamics of nuptiality and divorce. The tendencies in the number of marriages and divorces directly determine the family structure of the Croatian population and consequently, the trends in natality (fertility), because there are still about $90 \%$ of live born children born within marriages in Croatia.

In the period from 1971 to 2003, the number of marriages in Croatia made up 971,497 and the number of divorces 167,777 . The average general divorciality coefficient for the specified period was 173. When comparing the first (1971) and the last year (2003) in that 
period, it is evident that the number of marriages decreased by $40.8 \%$ and the number of divorces by $9.1 \%$. However, the change (increase) in the divorciality coefficient (from 144 to 221) points to an increasing significance of divorces in correlation with marriages, although when compared with its European neighbourhood, Croatia has a relatively low coefficient of divorciality. According to the data of the Council of Europe, in the year 2000 the divorciality coefficient was for Russia 795, Ukraine 719, Latvia 666, Belgium 598, Sweden 539, Czech Republic 537, Hungary 499, Denmark 370, Bulgaria 301, Portugal 300, Slovenia 295, Switzerland 264, etc. Divorciality coefficient lower than Croatia had only: Spain (178 in 1998), Serbia and Montenegro (137), Italy (125), Ireland (122), Macedonia (93), Albania (78 in 1999) and Bosnia and Herzegovina (66).

Tab. 3 Dynamics of made and divorced marriages in Croatia (1971 - 2003), index of change and the dynamics of divorciality coefficient change

Tab. 3 Kretanje broja sklopljenih i razvedenih brakova u Hrvatskoj u razdoblju 1971.-2003. godine, indeks promjene te kretanje koeficijenta divorcijaliteta

\begin{tabular}{|c|c|c|c|c|c|}
\hline Year & $\begin{array}{c}\text { Made } \\
\text { marriages }\end{array}$ & Chain index & $\begin{array}{c}\text { Divorced } \\
\text { marriages }\end{array}$ & Chain index & $\begin{array}{c}\text { Divorciality } \\
\text { coefficient }\end{array}$ \\
\hline 1971 & 37,701 & - & 5,427 & - & 144 \\
\hline 1972 & 37,779 & 100.2 & 5,567 & 102.6 & 147 \\
\hline 1973 & 36,967 & 97.9 & 5,781 & 103.8 & 156 \\
\hline 1974 & 36,034 & 97.5 & 6,331 & 109.5 & 176 \\
\hline 1975 & 36,290 & 100.7 & 5,928 & 93.6 & 163 \\
\hline 1976 & 35,019 & 96.5 & 6,099 & 102.9 & 174 \\
\hline 1977 & 35,524 & 101.4 & 5,511 & 90.4 & 155 \\
\hline 1978 & 35,629 & 100.3 & 5,959 & 108.1 & 167 \\
\hline 1979 & 34,041 & 95.5 & 5,036 & 84.5 & 148 \\
\hline 1980 & 33,310 & 97.9 & 5,342 & 106.1 & 160 \\
\hline 1981 & 33,855 & 101.6 & 5,704 & 106.8 & 169 \\
\hline 1982 & 33,143 & 97.9 & 5,355 & 93.9 & 162 \\
\hline 1983 & 33,135 & 99.9 & 5,263 & 98.3 & 159 \\
\hline 1984 & 32,161 & 97.1 & 5,295 & 100.6 & 165 \\
\hline 1985 & 30,953 & 96.2 & 5,375 & 101.5 & 174 \\
\hline 1986 & 30,495 & 98.5 & 5,946 & 110.6 & 195 \\
\hline 1987 & 31,395 & 103.0 & 5,577 & 93.8 & 178 \\
\hline 1988 & 29,719 & 94.7 & 5,647 & 101.3 & 190 \\
\hline 1989 & 28,938 & 97.4 & 5,369 & 95.1 & 186 \\
\hline 1990 & 27,924 & 96.5 & 5,466 & 101.8 & 196 \\
\hline 1991 & 21,583 & 77.3 & 4,877 & 89.2 & 226 \\
\hline 1992 & 22,169 & 102.7 & 3,676 & 75.4 & 166 \\
\hline 1993 & 23,021 & 103.8 & 4,667 & 127.0 & 203 \\
\hline 1994 & 23,966 & 104.1 & 4,630 & 99.2 & 193 \\
\hline 1995 & 24,385 & 101.7 & 4,236 & 91.5 & 174 \\
\hline 1996 & 24,596 & 100.9 & 3,612 & 85.3 & 147 \\
\hline
\end{tabular}




\begin{tabular}{|l|c|c|c|c|c|}
\hline 1997 & 24,517 & 99.7 & 3,899 & 107.9 & 159 \\
\hline 1998 & 24,234 & 98.8 & 3,962 & 101.6 & 164 \\
\hline 1999 & 23,778 & 98.1 & 3,721 & 93.9 & 157 \\
\hline 2000 & 22,017 & 92.6 & 4,419 & 118.8 & 201 \\
\hline 2001 & 22,076 & 100.3 & 4,670 & 105.7 & 212 \\
\hline 2002 & 22,806 & 103.3 & 4,496 & 96.3 & 197 \\
\hline 2003 & 22,337 & 97.9 & 4,934 & 109.7 & 221 \\
\hline
\end{tabular}

Source: Prirodno kretanje stanovništva 1971 - 2002. RZSSRH i DZSRH, Zagreb, 1973 - 2004. Priopćenje br. 7.1.1. Prirodnokretanje stanovništva RH u 2003. DZSRH, Zagreb, 2004.

The main reason for a decreasing number of marriages in Croatia in the investigated period was the long-term tendency of decline in the number of live births. That process was also contributed by several other factors, such as current socio-economic developments and changes in Croatia (changes in the economy-related population structure, intense migrations from rural areas into towns and abroad, demographic ageing, misbalance in sex structure of the population) and particularly by the war in the early1990s. The shift in the value system regarding marriage and family life in general also contributed to the mentioned processes. Due to rapid industrialization and urbanization many families (especially in rural areas) had to face a totally new social, demographic and cultural circumstances that were significantly different from the inherited ones (Živić, 2003, b).

These factors have also generated corresponding changes in the reproductive role of the family. In spite of the fact that around $90 \%$ of the children in Croatia are born into families it is also evident that there is a significant tendency of this trend declining. This is explained by a shift in attitude related to birth, marriage and family, as well as by the change in fertility rates out of wedlock, increase in the number of unmarried women and institutionalising the unmarried communities (Mrđen, 1997). A trend of "family uninstitutionalization" is present (Puljiz, 1995). In 1975 only 4.9\% of all live births were born out of wedlock. Until 1991 that number increased to $5.9 \%$, until 1995 to $7.5 \%$ and until 2002 it rose to $9.6 \%$. However, in comparison to most European countries, there is still a significantly higher number of children born within wedlock in Croatia. In the years 2000 or 2001 in Iceland were $65.2 \%$ of children born out of wedlock; in Estonia $56.2 \%$; in Sweden 55.5\%; Norway 49.7\%; Denmark 44.6\%; France 42.6\%; Latvia 42,1\%; Bulgaria 42.0\%; United Kingdom 40.1\%; Finland 39.5\%; Slovenia 39.4\%; Austria 33.1\%; Ireland $31.2 \%$; Hungary $30.3 \%$, etc. ${ }^{7}$ In 2000 , the European countries besides Croatia, with less than $11 \%$ of children born out of wedlock were: Greece (3.9\% in 1999), Macedonia (9.8\%), Bosnia and Herzegovina (10.1\% in 1998) and Italy $(10.2 \%)^{8}$.

\section{EMIGRATIONAL DEPOPULATION OF CROATIA 1991 - 2001}

The results of the 2001 census, along with the vital statistics data for the investigated period allow the rough estimates of the migratory change between the years 1991 and 2001. Taking into account that both the 2001 and 1991 census make distinction between the contingent of the population actually present in the country and the one that is absent, it is methodologically acceptable to base the estimation of migratory change on de facto 
number of inhabitants from both censuses, even though these data are not fully comparable. In 1991, in the country were censused $4.499,049$ persons and in 2001, that number was $4.211,309$ persons $^{9}$. The absolute change of de facto population between the two censuses was negative, and amounted to 287,740 persons. Over the past decade, at least 232,966 persons ${ }^{10}$ have immigrated into Croatia. In 2001, an expected (estimated) number of the Croatian population, based only on the number of immigrants, would be $4.732,015$. In that case, the difference between the actually censused and expected number would be $-520,706$ persons. By subtracting from that figure the number representing natural decrease of the population in the period 1991-2001, that is 65,409 persons ${ }^{11}$, the estimated total number of emigrants from Croatia for the period 1991-2001 is obtained amounting to 455,297 persons. According to the available data, 268,507 emigrated (exiled) Serbs from Croatia were registered in 2001 in Serbia and Montenegro and in Bosnia and Herzegovina $^{12}$, which leads to the conclusion that in "regular" emigrations, between 180 and 190 thousands of persons left Croatia. From the above data, it is possible to roughly estimate that in the period 1991-2001 Croatia had negative migratory balance (more emigrated that immigrated) of 222,331 person.

Considering the fact that emigrated population includes mainly young persons (20-40 years of age) most capable for work and reproduction, it is evident that emigrational depopulation not only significantly affects the total and natural dynamics of the population and development of the age-sex and economy-related structure of the population, but plays a decisive role in terms of prosperity of the overall population development.

\section{POPULATION AGEING IN CROATIA}

Age and sex structure of the population is the most important demographic structure due to a number of reasons. Its primary significance issues from the fact that it represents the demographic frame for forming the reproductive (vital) and working (labour contingent) potential of the population. The tendencies of its development directly determine the natural and migratory dynamics of the population, and therefore they also affect the total demographic dynamics (population change) of a certain area. In other words, the processes in the development of age and sex structure of the Croatian population result from, but also determine all relevant factors and components of total and natural depopulation in Croatia. It is mainly the result of the fact that all the processes involved in shaping age and sex structure of the Croatian population over the past fifty years were marked by negative developmental traits.

When the changes in the age and sex structure of the Croatian population are considered, it is important to stress that they result from previously mentioned destabilizing factors of the demographic development. Among them, the negative tendency in the natality dynamics, emigration and war losses during both world wars as well as during the Croatian Homeland War are the most important.

The most important process in the development of age and sex structure of the Croatian population, that has long-term and deep consequences to total demographic and socio-economic development is an accelerated process of demographic ageing and related increase in the number of old-aged population (Nejašmić, 2003). Furthermore, the ageing 
Tab. 4 Selected indicators and gender structure of the population according to 1961, 1971, 1981, 1991 and 2001 censuses

Tab. 4. Odabrani pokazatelji dobno-spolne strukture stanovništva Hrvatske prema popisima 1961., 1971., 1981., 1991. i 2001.godine

\begin{tabular}{|l|c|c|c|c|c|}
\hline \multicolumn{1}{|c|}{ INDICATORS } & $\mathbf{1 9 6 1}$ & $\mathbf{1 9 7 1}$ & $\mathbf{1 9 8 1}$ & $\mathbf{1 9 9 1}$ & $\mathbf{2 0 0 1}$ \\
\hline Coefficient of femininity & 109.4 & 106.9 & 106.6 & 106.3 & 107.8 \\
\hline Youth coefficient & 34.3 & 31.5 & 28.2 & 26.2 & 23.7 \\
\hline Older age coefficient & 11.8 & 14.9 & 14.8 & 17.5 & 21.5 \\
\hline Index of ageing & 34.3 & 47.2 & 52.6 & 66.7 & 90.7 \\
\hline Specific coefficient of the young population & 97.2 & 96.2 & 95.4 & 95.3 & 95.5 \\
\hline Specific coefficient of the mature population & 111.3 & 105.6 & 102.2 & 98.2 & 100.4 \\
\hline Specific coefficient of the old population & 144.0 & 140.3 & 154.6 & 161.2 & 147.7 \\
\hline $\begin{array}{l}\text { The contingent of the population before } \\
\text { working age (\%) }\end{array}$ & 27.2 & 22.6 & 20.9 & 19.4 & 17.0 \\
\hline $\begin{array}{l}\text { Contingent of the population in the working } \\
\text { age (\%) }\end{array}$ & 65.3 & 67.2 & 66.9 & 67.5 & 66.9 \\
\hline $\begin{array}{l}\text { The contingent of the population after } \\
\text { working age (\%) }\end{array}$ & 7.4 & 9.6 & 11.4 & 11.6 & 15.6 \\
\hline Coefficient of the total age dependency & 53.1 & 48.1 & 48.4 & 45.9 & 48.8 \\
\hline $\begin{array}{l}\text { Coefficient of age dependency of the young } \\
\text { population }\end{array}$ & 41.7 & 33.7 & 31.3 & 28.7 & 25.4 \\
\hline $\begin{array}{l}\text { Coefficient of age dependency of the old } \\
\text { population }\end{array}$ & 11.4 & 14.4 & 17.0 & 17.2 & 23.4 \\
\hline
\end{tabular}

Source: Popis stanovništva 2001., Statističko izvješće 1167, Stanovništvo prema spolu i starosti, po naseljima, DZSRH, Zagreb, 2003.

of the total population is not the only process; there are also significant processes of partial ageing of the population which involve ageing of particular functional age contingents, such as working-age population, population in the fertile age, or of labour contingent, etc. (Wertheimer-Baletić, 2002). The simplest indicator of ageing of the population is the reduction in number and percentage of young population (younger than 19 years of age - the youth coefficient) and increase in number and percentage of aged population (older than 60 years - the ageing coefficient) in total population. In the period from 1961 to 2001, the youth coefficient in the Croatian population decreased from 34.3 to 23.7, whereas the ageing coefficient increased from 11.8 to 21.5 . In other words, the percentage of young population in the total population of Croatia dropped below one quarter, while the percentage of old population rose above one fifth of the entire population. In the same period, the percentage of the population younger than 14 years of age fell from $27.2 \%$ to $17.0 \%$, whereas the percentage of the population older than 65 years of age rose from $7.4 \%$ to $15.6 \%$, which means that it was doubled! In spite of different classifications of age structure of population by the types of age structure of the population, it is more than obvious that in early 1960s, Croatia was at the edge of ageing. Consequently, as early as in 1971, Croatia belonged to the circle of countries characterized by demographic oldness. As shown by the 2001 census, by the type of age structure of its population, Croatia is the country of deep ageing (Živić, 2003, a). 
It is important to stress that negative changes in the age and sex structure of the Croatian population actually represent the continuation of past tendencies of an expanding disproportion between the large age groups, which have long-term and markedly unfavourable effects on demographic, social and economic development of Croatia. This can be best confirmed by the index of ageing (from 52.6 to 90.7).

The drop in the number and percentage of young population, especially of the female population in pre-fertile age, results in a decreased population influx in the fertile (reproductive age) population group, which further implies decreased vitality and new negative tendencies in demographic reproduction, especially in the natality dynamics. In the theory of demography, that process is called the effect of the generation shift (Wertheimer-Baletić, 1999). In the period from 1971 to 2001, the percentage of the female population in pre-fertile age (younger than 14 years of age) declined from $21.5 \%$ to $16 \%$ (the number of female population in this contingent is reduced for one quarter). The number of female population in the fertile age $(15-49$ years $)$ declined as well - from $51.4 \%$ to $46.0 \%$. However, in the same period, the number of women in post-fertile age (older than 50 years of age) grew by almost $40 \%$ and led to the increase of that specific contingent of female population in the total female population from 26.6 $\%$ to as much as $36.6 \%$.

According to the 2001 census, almost half of the fertile contingent of the female population (45.5\%) is older than 35 years of age, which is considered an explicit age limit between the periods of more and less frequent births (more than $80 \%$ of women give birth before 35 years of age $)^{13}$.

The constant decline in the number and percentage of young population affects the overall potential of the population capable for work and of those that actually participate in labour force. Therefore, these processes negatively determine the total activity of the population and the level of socio-economic development of the country. The changes in the age structure of the population capable to work are important determinants of the employment and labour force, because the ageing of the working contingent points to the partial process of labour-force ageing, which has deep and long-term demographic and in particular socio-economic impacts. In close future this process may cause the deficit of the labour force, which indicates the need for creating and applying adequate measures of (selective) economic immigration policy. From the number of indicators obtained in past researches, it is evident that current demographic dynamics in Croatia does not guarantee the sustainable development of the labour force, which directly endangers both the economic activity and retirement system. Increase in the number and percentage of old population causes the slight increase in the mortality (the generations with an increased risk of death are more numerous), but also the high increase in necessary financial and other means of care for older persons such as retirement funds, health and social insurance. This undoubtedly represents an additional burden for already disturbed and negative economic trends in the country. 


\section{PROJECTIONS OF THE CROATIAN POPULATION BY THE MIDDLE OF THE CENTURY, OR: WHERE IS CROATIA GOING?}

As shown by numerous researches (analyses and projections), the negative processes in the natural dynamics of the population, emigration of the vitally and working most potent population, as well as the process of the population ageing will undoubtedly reflect to the further disturbances in the development of the Croatian population in view of the change in the number of inhabitants and development of the demographic structures, age and sex structure in particular. Croatia will continue to go backward in its population development. According to the moderate version of the projection of the number of inhabitants, provided by the UN's Population Division demographers, by the year 2050 Croatia is expected to loose one fifth of its population ${ }^{14}$. In other words, in 2050 the Croatian population will number approximately $3.587,000$, which is 850,000 inhabitants less than at the beginning of the century ${ }^{15}$. In the same period (2003-2050) total depopulation of the European population will be one-half lower (-13.0\%) in comparison with the projected total depopulation of Croatia ${ }^{16}$. On the other hand, the population of the World will in the same period grow by $41.5 \%$.

The projected demographic loss will be the consequence of low fertility rates (very low total fertility rates). As stated before, the total fertility rate in Croatia had been for more than thirty years below the critical level of 2.1, which ensures the simple generational reproduction of the population. The UN demographers forecasted that the total fertility rate would remain below the mentioned level in the next 50 years, which is the basic factor of deterioration of demographic processes in the rest of this century ${ }^{17}$.

Even worse are projections of age structure of the population, done by UN's Population Division. According to their predictions, until 2050, the percentage of the Croatian population younger than the age of 14 would be reduced to $15.8 \%$ (17\% in 2001). The percentage of the Croatian population between 15 and 64 years would be reduced to $59.1 \%$ (66.9\% in 2001) and the percentage of the population older than 65 would be increased to as much as $25.1 \%(15.6 \% \text { in } 2001)^{18}$. Thus, until the middle of this century the number and percentage of old population can be expected to almost double in comparison to the number and percentage of young population, which is the basis of demographic and labour reproduction. Croatia will then be listed among the European countries with the oldest population (Wertheimer-Baletić, 2001).

\section{CONCLUSION}

The present-day Croatia is in a deep demographic crisis. Its roots can be found in the complex and prevailingly disturbing, "interior" and "exterior" determinants of the demographic development. Negative demographic processes in Croatia are unquestionably one of dominant factors of its social and economic crisis. The current development of the Croatian population involves the long-term basic demographic processes of total 
and natural depopulation, and of population ageing. Long-term character of demographic changes along with the increasingly unfavourable tendencies of the population development and their deteriorating effect on the overall socio-economic development of the country, point to a need for an immediate action. An elaborately planned active concept should be designed with regard to the population and family policy, supported by the forming a positive social atmosphere that encourages family life, marriage and children and promotes responsible parenthood. Adequate steps should be taken to enable economic growth that is capable to meet the employment requirements, and will offer better housing solutions and involve a number of population and family related incentives in the domain of labour and tax regulations.

\section{NOTES}

1. In the 2001 census an international census methodology was partially applied, according to which only the population present in the country (de facto) was considered as country's population. Newly applied methodology uses also a new definition of usual resident population. As the criteria for defining it, the place of usual residence with absence time limit of one year was taken. Because of complicated census criteria for defining the present population of Croatia, the comparison of census results from the year 2001 and the results form previous censuses is made more difficult. Namely, the definition of the present population in the 1971, 1981 and 1991 censuses is not completely identical with the definition of the 2001 census. In the previous censuses, the minimum presence time in the census area of one year was not considered as a criterium for defining the presence of the population. There are also the problems regarding the census definition and defining the Croatian population abroad, which is absent from the country. For more details regarding the methodology of the 2001 census and some methodological problems related with the comparison of the census results from the mentioned census and 1991 census, see: Gelo (2004), Pokos (2003) and Wertheimer-Baletić (2003).

2. Total fertility rate represents the probable number of live born children by one average female of the explored generation in her fertile period under the effect of affection of current specific fertility rates per age groups with the abstraction of mortality influence.

3. Source: Recent demographic developments in Europe 2002, Council of Europe Publishing, Council of Europe, Strasbourg, December 2002.

4. Noted number includes the official data of Croatian vital statistics, which are enlisted into state registers of died persons and estimated war mortality of Serbs in Croatian areas that were occupied during the war.

5. Source: Demographic year book, edition 2001, Council of Europe (www.coe.int)

6. Source: Monnier and Guibert-Lantione, 1996: Statistički ljetopis Republike Hrvatske 2002.,DZSRH, Zagreb, 2004.

7. One quarter of century earlier in Iceland only $33.0 \%$ of children were born out of wedlock; in Estonia $15.6 \%$; Sweden 32.4\%; Norway 10.3\%; Denmark 21.7\%; France 8.5\%; Latvia 6.2\%; United Kingdom 9.0\%; Finland $10.1 \%$; Slovenia 9.8\%; Austria 13.5\%; Ireland 3.7\%; Hungary 5.6\%, etc. (according to Monnier and GuibertLantione, 1996)

8. According to: Demographic Year Book, Edition 2001, Council of Europe (www.coe.int)

9. In de facto number of inhabitants for 2001 census, considered were: population present in the time of the census, population that is absent, but in the country, refugees in Croatia and temporary present persons.

10. That number of immigrants was registered in 2001 census. Those are immigrants that after immigration to Croatia did not change the place of residence, because according to methodological notes, if the person moved more that one time, only a note of the last moving was registered. 
11. The stated number includes the official data for the vital statistics of Croatia, enlisted into state registers of died persons afterwards, and estimated war mortality of Serbs from Croatia in areas that were occupied during the war.

12. Data according to: Izvješće o povratku prognanika i izbjeglica u Republici Hrvatskoj od 2000 - 2003: Povrat imovine, stambeno zbrinjavanje, obnova, Ministarstvo za javne radove, obnovu i graditeljstvo, Zagreb, October 2003.

13. According to the data from the year $2002,89 \%$ of women of Croatia gave the birth before 35 years of age (Source: Statistički ljetopis RH 2003., Zagreb, 2004)

14. According to the projection made by Ivo Nejašmić and Roko Mišetić (2004), the change of the population until 2031 will be $-17.1 \%$. A slightly different projection of the population change (until 2031) in Croatia was offered by Snježana Mrđen. Her projections differ from those of UN demographers in the hypothesis that "the population change in the next three decades will follow the middle version of projections that includes the migratory component (Mrđen, 2004, 65).

15. According to: World Population Prospects, The 2002 Revision, United Nation Population Division, New York, 2003.

16. Compared to Croatia, higher total depopulation would have the following countries: Estonia (-50.3\%), Latvia $(-42.3 \%)$, Ukraine $(-34.6 \%)$, Bulgaria $(-33.5 \%)$, Russia $(-29.2 \%)$, Lithuania $(-26.7 \%)$, Belarus $(-23.8 \%)$, Hungary (-23.2\%), Italy (-21.9\%), Slovenia (-20.9\%), Romania $(-19.1 \%)$, etc. Lowed drop of the population in the same period would have: Belgium $(-0.9 \%)$, Denmark $(-1.7 \%)$, Sweden $(-2.0 \%)$, Germany $(-4.0 \%)$, Slovakia (-8.4\%), Austria (-9.1\%), Spain (-9.1\%), Portugal $(-10.3 \%)$, Greece $(-10.6 \%)$, Serbia and Montenegro $(-11.0 \%)$, Bosnia and Herzegovina $(-14.3 \%)$, Poland $(-14.5 \%)$, Moldova $(-16.1 \%)$, Czech Republic $(-16.4 \%)$, etc. According to the projections made by UN demographers, the population growth in the same period will have the following European countries: Andorra (132.4\%), Luxembourg (58.1\%), Ireland (26.3\%), Albania (15.9\%), Iceland (13.8\%), United Kingdom (11.7\%), Norway (7.5\%), France (6.8\%), Netherlands $(5.0 \%)$, Macedonia (4.9\%), Malta (2.0\%), etc. (Source: World Population 2002, United Nations, Population Division, Department of Economic and Social Affairs, New York, 2002)

17. When other European countries are considered, the UN demographers forecast that in the period $2000-2005$ only Albania will have the average total fertility rate that will ensure expanded reproduction of the population (2.3). In other European countries the total fertility rate will be below 2.1; form lowest 1.1 in Bulgaria, Russia, Latvia and Slovenia to highest 2.0 in Iceland (1.9 in Ireland, Macedonia and France).

18. Source: Population Division of the Department of Economic and Social Affairs of the United Nations Secretariat, World Population Prospects: The 2002 Revision and World Urbanisation Prospects: The 2001 Revision, http://esa.un.org/unpp

\section{REFERENCES}

Akrap, A. 1998.: Saldo migracija Republike Hrvatske i županija 1971.-1981. i 1981.-1991. za ukupno stanovništvo i stanovništvo u zemlji, Migracije u Hrvatskoj - regionalni pristup, Institut za migracije i narodnosti, Zagreb, 11-68.

Akrap, A. 2003.: Migracija Hrvata u posljednjem desetljeću 20. stoljeća,, Hrvatska dijaspora u Crkvi i domovini, Hrvatski dušobrižnički ured, Frankfurt am Main,, 23-55.

Gelo, J. 1999.: Ratni učinci na promjene demografskih struktura u Hrvatskoj, Društvena istraživanja, Vol. 8, No. 5-6 (43-44), 735-750.

Gelo, J. 2004.: Kretanje broja rezidencijalnoga (boravećeg) stanovništva Hrvatske u 20. stoljeću, Društvena istraživanja, Vol. 13, No. 4-5 (72-73), 653-673.

Monnier, A., Guibert-Lantoine, C. 1996.: The demographic situation of Europe and the developed countries overseas: An annual report, Population: An English Selection, Vol. 8, 235-250. 
Mrđen, S. 1997.: Rađanja izvan braka u Hrvatskoj, Geoadria, Vol. 2, 63-76.

Mrđen, S. 2004.: Projekcije stanovništva Republike Hrvatske do 2031. godine: mogu li migracije ublažiti buduće negativne demografske trendove?, Migracijske i etničke teme, Vol. 20, No. 1, 63-78.

Nejašmić, I. 1991.: Iseljavanje iz Hrvatske - brojčani aspekt stoljetnog procesa, Političko-geografska i demografska pitanja Hrvatske, SGD Hrvatske, Zagreb, 61-82.

Nejašmić, I. 2003.: Značajke biološkog (demografskog) sastava stanovništva Hrvatske, Hrvatski geografski glasnik, Vol. 65, No. 2, 29-54.

Nejašmić, I. i Mišetić, R. 2004: Buduće kretanje broja stanovnika Hrvatske: projekcija 2001. - 2031. Društvena istraživanja, Vol. 13, No. 4-5 (72-73), 751-776.

Pokos, N. 1999.: Procjena broja iseljenih stanovnika Republike Hrvatske od popisa stanovništva 1991. do 30. lipnja 1998. godine, Društvena istraživanja, Vol. 8, No. 5-6 (43-44), 725-734.

Pokos, N. 2003.: Metodološke promjene u popisima stanovništva, Hrvatska revija, Vol. III., No. 1, 29-35.

Puljiz, V. 1995.: Demografski procesi i struktura obitelji (europska iskustva), Revija za socijalnu politiku, Vol. II, No. 2, 123-130.

Wertheimer-Baletić, A. 1992.: Demografske promjene i globalni demografski procesi u Hrvatskoj u poslijeratnom razdoblju, Encyclopaedia Moderna, Vol. XIII, No. 2 (38), 238-250.

Wertheimer-Baletić, A. 1996.: Specifičnosti demografskog razvitka u Hrvatskoj i njegove socio-ekonomske implikacije, Revija za socijalnu politiku, Vol. III., No. 3-4, 251-258.

Wertheimer-Baletić, A. 1999.: Stanovništvo i razvoj, MATE, Biblioteka Gospodarska misao, Zagreb.

Wertheimer-Baletić, A. 2001.: Stanovništvo Hrvatske - sadašnje stanje i buduće promjene, Rad Hrvatske akademije znanosti i umjetnosti, Vol. XXXIX., No. 482, 109-125.

Wertheimet-Baletić, A. 2002.: Reprodukcija radno-sposobnog stanovništva u Hrvatskoj, Zbornik uz 70-godišnjicu Dragutina Pavličevića, Institut društvenih znanosti Ivo Pilar, Zagreb, 421-429.

Wertheimer-Baletić, A. 2003.: Sastavnice demografske bilance Hrvatske prema popisu stanovništva 2001. godine, Hrvatski identitet u Europskoj uniji, Centar za promicanje socijalnog nauka Crkve, Glas Koncila, Zagreb, 117-138.

Wertheimer-Baletić, A. 2004.: Depopulacija i starenje stanovništva - temeljni demografski procesi u Hrvatskoj, Društvena istraživanja, Vol. 13, No. 4-5 (72-73),631-652.

Živić, D. 1999.: Promjene u dinamici i razmještaju prognaničko-izbjegličkog kontingenta u Republici Hrvatskoj od sredine 1991. do sredine 1998. godine, Društvena istraživanja, Vol. 8, No. 5-6 (43-44), 767-792.

Živić, D. 2001.: Izravni demografski gubitci (ratne žrtve) Hrvatske (1990.-1998.) uzrokovani velikosrpskom agresijom i neke njihove posljedice, Društvena istraživanja, Vol. 10, No.53, 451-484.

Živić, D. i Pokos, N. 2002.: Prisilne i druge ratom uzrokovane migracije stanovništva Hrvatske 1991.-2001., Zbornik uz 70-godišnjicu Dragutina Pavličevića, Institut društvenih znanosti Ivo Pilar, Zagreb, 430-443.

Živić, D. 2003.a.: Demografski okvir i razvoj obiteljske strukture stanovništva Hrvatske 1971.-2001., Revija za sociologiju, Vol. XXXIV, No. 1-2, 57-73.

Živić, D. 2003.b.: Demografske odrednice i posljedice starenja stanovništva Hrvatske, Revija za socijalnu politiku, Vol. 10, No. 3-4, 307-319.

Živić, D. i Pokos, N. 2004.: Demografski gubitci tijekom domovinskog rata kao odrednica depopulacije Hrvatske (1991.-2001.), Društvena istraživanja, Vol. 13, No. 4-5 (72-73), 727-750. 


\title{
SAŽETAK
}

\section{Glavni demografski procesi u Hrvatskoj}

\author{
Dražen Živić, Nenad Pokos, Ivo Turk
}

Razvoj stanovništva Hrvatske u suvremenom razdoblju (nakon Drugoga svjetskog rata) karakterizira nekoliko općih i parcijalnih (specifičnih) demografskih procesa izrazito depopulacijskih značajki, među kojima su najznačajniji procesi ukupne i prirodne depopulacije te demografskog starenja. Ti su dugoročni demografski procesi, u međusobnoj kauzalnosti i s dalekosežnim posljedicama, postali bitnim remetilačkim čimbenikom stabilnog i prirodnog populacijskog, ali i društveno-gospodarskog razvoja Hrvatske. Rezultanta je to uzročno-posljedične uvjetovanosti i prožetosti različitih «unutarnjih» $\mathrm{i}$ «vanjskih» odrednica demografskog razvoja, od kojih su mnoge na razvoj stanovništva Hrvatske djelovale ili još uvijek djeluju destabilizacijski. U tom smislu valja istaknuti da se razvoj stanovništva Hrvatske tijekom posljednjih stotinjak i nešto više godina odvijao pod utjecajem kontinuiranog, a povremeno i vrlo intenzivnog europskog i prekomorskog iseljavanja, nepovoljnog utjecaja dvaju svjetskih ratova, bolesti i čestih epidemija, poput kolere i španjolske gripe, čestih i dubokih gospodarskih kriza, napose kriza u agrarnoj proizvodnji, ekonomske emigracije započete 1960-ih godina, dijelom nekontrolirane, pa i prisilne deagrarizacije i deruralizacije te brze i pretjerane urbanizacije.

Migracije su iznimno značajna demografska odrednica razvoja stanovništva Hrvatske. Njihov se utjecaj ogleda, kako u promjenama broja i razmještaja stanovništva, tako i u razvoju demografskih struktura, napose etničko-religijskog sastava stanovništva. Uz gospodarske i političke čimbenike migracijskih kretanja, na prostornu dinamiku stanovništva Hrvatske uvelike su utjecala i ratna zbivanja i stradanja.

Djelovanje navedenih destabilizacijskih odrednica na razvoj stanovništva Hrvatske u 1990-tim godinama bilo je pojačano izostankom bilo kakve cjelovite, dugoročne i stimulativne populacijske i obiteljske politike, napose u domeni kretanja nataliteta, te Domovinskim ratom, koji je zbog relativno visokih stvarnih (izravnih i migracijskih) i neizravnih demografskih gubitaka doveo do pojačavanja brojnih negativnih te zaustavljanja ionako rijetkih pozitivnih procesa u razvoju stanovništva Hrvatske.

Hrvatska je prvi puta nakon Drugoga svjetskog rata pad/smanjenje/depopulaciju broja stanovnika zabilježila tijekom posljednjega međupopisnog razdoblja (1991.-2001.). Međutim, ukupna depopulacija stanovništva dugoročan je proces - kojemu prethode ili kojega ga determiniraju - različiti parcijalni depopulacijski procesi, poput prirodne, generacijske, reprodukcijske i emigracijske depopulacije. Naime, Hrvatska već duže vrijeme bilježi usporavanje stopa demografskog rasta. Prosječna godišnja stopa porasta broja stanovnika Hrvatske se od 1953. do 1991. godine nalazila u stalnom padu (sa 0,8\% u razdoblju 1948.-1953. na 0,4\% u razdoblju 1981.-1991. godine).

Između 1991. i 2001. godine broj stanovnika u Hrvatskoj smanjen za gotovo 350 tisuća osoba ili za oko 7,2\%. Primijenimo li na rezultate popisa 2001. definiciju ukupnog stanovništva («de iure») kakva je bila 1991. godine, onda ukupna depopulacija u Hrvatskoj iznosi 6,1\%, a ako usporedimo samo stanovništvo popisano u zemlji («de facto»), onda bi ukupna depopulacija u Hrvatskoj iznosila 6,6\%.

Nepovoljne tendencije u prirodnom kretanju stanovništva, napose u dinamici nataliteta, već su tri do četiri desetljeća jedan od najvažnijih «unutarnjih» destabilizacijskih čimbenika razvoja stanovništva Hrvatske. U tom kontekstu osobito valja istaknuti višegodišnji, gotovo kontinuirani pad broja živorođenih (i stopa nataliteta) u Hrvatskoj te pad totalne stope fertiliteta, opće stope fertiliteta, kao i specifičnih stopa fertiliteta po dobi, te stope neto-reprodukcije stanovništva. Istodobno, mortalitet (broj umrlih i stope) nalazile su se u blagom, ali gotovo stalnom porastu. Hrvatska je zahvaljujući sve nepovoljnijim trendovima u prirodnoj dinamici «izgubila» onu jezgru stanovništva koja stvara nove naraštaje ili koje sudjeluje u društvenoj podjeli rada. Jer, sve manji natalitet implicira sve manji priljev stanovništva u mlade dobne skupine, koje predstavljaju demografski okvir formiranja reprodukcijskih i radno-aktivnih kontingenata stanovništva. 
Najvažniji proces u razvoju dobno-spolne strukture stanovništva Hrvatske, s dalekosežnim i teškim posljedicama po ukupan demografski i društveno-gospodarski razvoj jest ubrzani proces demografskog starenja i vrlo visoki stupanj ostarjelosti ukupnog stanovništva. $\mathrm{K}$ tome, ne radi se samo o starenju ukupnog stanovništva, nego i o parcijalnim procesima starenja, koji se sastoje u starenju pojedinih funkcionalnih dobnih kontingenata, primjerice, stanovništva u radno-sposobnoj dobi, fertilnog kontingenta stanovništva, radno-aktivnog stanovništva (radne snage) i slično. Bez obzira na primjenu različitih klasifikacija dobne strukture prema tipovima dobnog sastava stanovništva, više je nego očito da se Hrvatska već na početku 1960-ih godina nalazila na pragu demografskog starenja. U krug zemalja s tipom demografska starost Hrvatska je ušla već 1971. godine. Popis stanovništva 2001. godine je pokazao da je prema tipu dobnog sastava Hrvatska zemlja duboke starosti. Valja naglasiti da su (negativne) promjene u dobno-spolnoj strukturi stanovništva Hrvatske nastavak dosadašnjih tendencija povećanja disproporcije između velikih dobnih grupa, što ima dugoročne i vrlo nepovoljne posljedice po demografski, društveni i gospodarski razvoj Hrvatske.

Sve manji broj i udjel mladog stanovništva smanjuje potencijale obujma radno-sposobnog i radno-aktivnog stanovništva, što negativno određuje ukupnu aktivnost stanovništva, pa i razinu društveno-gospodarskog razvoja zemlje. Promjene u dobnoj strukturi radno-sposobnog stanovništva bitna su odrednica dinamike radne snage i zaposlenosti, jer starenje radnog kontingenta implicira parcijalni proces starenja radne snage, što ima duboke i dalekosežne demografske i naročito društveno-gospodarske posljedice. Potonje u neposrednoj budućnosti može izazvati i manjak radne snage, što implicira osmišljavanje i provođenje odgovarajućih mjera (selektivne) ekonomske imigracijske politike. Iz niza je pokazatelja razvidno da postojeća demografska kretanja u Hrvatskoj ne osiguravaju održiv razvoj radne snage, što izravno ugrožava, ne samo ekonomsku aktivnost, nego i mirovinski sustav. Porast broja i udjela starog stanovništva utječe na blagi porast mortaliteta (sve su brojniji naraštaji s većim rizikom smrti), ali i na naglašeno visok porast potrebnih financijskih i drugih sredstava za mirovinsko, zdravstveno i socijalno zbrinjavanje starih osoba, što - nedvojbeno je - predstavlja dodatno opterećenje za ionako poremećene i posrnule gospodarske tokove u zemlji.

Hrvatska se danas nalazi, dakle, u dubokoj demografskoj krizi. Korijene uzroka te krize nalazimo u složenim «unutarnjim» $\mathrm{i}$ «vanjskim», uglavnom remetilačkim odrednicama demografskog razvoja. Nema nikakve sumnje da su nepovoljni demografski procesi u Hrvatskoj jedan od dominantnih čimbenika njezine društvene i gospodarske krize. Zbog dugoročnog karaktera demografskih promjena, zbog sve nepovoljnijih tendencija u razvoju stanovništva, te zbog njihova - kao što je već istaknuto - regresijskog učinka na društveno-gospodarski razvoj, potreban je neodgodiv, cjelovito promišljen i proveden aktivan koncept populacijske i obiteljske politike, što mora biti podržano stvaranjem pozitivnog društvenog ozračja ili raspoloženja za djecu, brak i obitelj, afirmiranjem odgovornog roditeljstva, gospodarskim rastom koji će omogućiti zapošljavanje, lakšim rješavanjem stambenog pitanja i nizom drugih poticajnih mjera populacijske i obiteljske politike iz domene radnog i poreznog zakonodavstva.

Received (Primljeno): 2004 - 11 - 18 Accepted (Prihvaćeno): 2005 - 5 - 11
Dražen Živić, Ph.D., Research Associate, Institute of Social Sciences Ivo Pilar, Marulićev trg 19/I, 10000 Zagreb, Croatia

E-mail: Drazen.Zivic@pilar.hr

Nenad Pokos, Ph.D., Research Associate, Institute of Social Sciences Ivo Pilar, Marulićev trg 19/I, 10000 Zagreb, Croatia E-mail: Nenad.Pokos@pilar.hr

Ivo Turk, B.Sc., Assistant Researcher, Institute of Social Sciences Ivo Pilar, Marulićev trg 19/I, 10000 Zagreb, Croatia

E-mail: Ivo.Turk@pilar.hr 